\title{
Does the Mode of Opportunity Identification Influence the Innovativeness of Small Businesses? A Study in Sri Lanka
}

\author{
W.A. Upananda ${ }^{1}$ and U.E.S. Kumara ${ }^{2}$ \\ ${ }^{1}$ Department of Banking and Finance, Faculty of Business Studies and Finance, \\ Wayamba University of Sri Lanka \\ uwitta@yahoo.com \\ ${ }^{2}$ Department of Accountancy, Faculty of Business Studies and Finance, Wayamba \\ University of Sri Lanka \\ emilkumara@yahoo.com
}

\begin{abstract}
There is a growing concern about the heterogeneity of the nature of small businesses in a given context. The difference between opportunity discovery and creation (mode of opportunity identification) may explain this heterogeneity. Then the wealth creating ability also may vary with the mode of opportunity identification although entrepreneurship literature is silent in this regard. Then the purpose of this study is to explore the wealth creating potential (innovativeness) of small businesses with regard to the mode of opportunity identification. Entrepreneurship literature informs that opportunity discovery under risk is different from opportunity creation under uncertainty although these terms has been used interchangeably. Few studies show that context may have influence over the opportunity identification. Few studies show that entrepreneurs who create opportunities are ordinary and attempt to avoid uncertainty while those who discover opportunities are unique in ability of discovering opportunities and bear some risk. However studies which explore the relationship between the wealth creating potential and mode of opportunity identification are rare. Exploring gaps in research knowledge base on the nature of businesses emerged under opportunity discovery and opportunity creation with regard to research question 'How the mode of opportunity identification influences the innovativeness of small businesses'. In consistent with entrepreneurship literature, the nature of business viewed in this study as wealth creating potential.
\end{abstract}

This study builds on theories and assumptions pertinent to opportunity discovery and creation and employs case study method to explore the behaviour of small business owners in rural and urban settings. The rationale of selecting rural setting is that rural entrepreneur has no prior business experience to understand the probability of outcomes while urban entrepreneurs have prior business experience to understand the probability of outcomes to take calculated risk. This study has selected six cases after screening 178 cases in the rural setting and 111 cases in the urban settings in the North Western 
Province of Sri Lanka in 2010. Analysing within cases and cross cases employing pattern matching technique, this study shows that businesses created in the rural context are comparatively non-innovative than those small businesses discovered under opportunity risk.

Keywords: Entrepreneurship, Opportunity Discovery, Opportunity Creation, Risk, Uncertainty

\section{Introduction}

Heterogeneity of innovativeness of small business is universal. Variation of capabilities of among entrepreneurs may explain this heterogeneity to some extent. Variation of mode of exploitation may explain this heterogeneity further. Mode of opportunity identification and wealth creating capacity, according entrepreneurship literature, may influence by the context (Zahra, 2007; Welter, 2010). The, context, in turn, either conducive for uncertainty avoidance or mitigate risk according to the institutions introduced (formal) or informal institutions evolve over time (North, 1990, 1991).

Entrepreneurs in rural setting which evolved only to survive may do not have prior business experience to understand the probability of outcomes of exploiting the identified opportunity while urban entrepreneurs may have prior knowledge (Shane, 2003) about the probability of outcomes. Although discovery and creation of business opportunities have been used interchangeably in entrepreneurship literature, only some researches state assumptions on opportunity discovery or creation at the outset. Researches who examine relationship between opportunity discovery or creation and the innovativeness of businesses are rare creating a major gap in entrepreneurship knowledge base. This study attempts to address this gap by raising research question 'how does the mode of opportunity identification influence the innovativeness of small businesses'. In consistent with literature, the innovativeness of small business referred in this study is proxy to wealth creating ability (Ucbasaran et al., 2009). 
The rest of this article is organized in order to address this question in the following manner. Next section will introduce the problem and then objectives of this study while second section gives brief description of pertinent theories and frames argument to address the research question. On the theoretical framework developed in the second section on reviewed literature, third section will spell out the method to implement the research. Fourth section deals with presentation and analysis of data, and the fifth section presents discussion on findings. Finally sixth section gives out the conclusion of this study.

\subsection{Problem background and Research Question}

Generally, innovativeness/wealth creating potential of businesses varies in a given context and across contexts. Different capabilities of individuals who exploit opportunities may explain this variation (Shane, 2000, 2003). Some researchers explored (e.g., Welter, 2010; John, 2006) that context may influence the phenomenon (opportunity identification behaviour in this study) while some researchers argue that the incentive structure for exchange may determines extent of this influence (North, 1990, 1991). Mode of opportunity identification, according to literature, is mainly in two types: opportunity creation and discovery (Alvarez and Barney, 2007). Proponents of opportunity discovery (Shane, 2000) assume opportunities are waiting to be discovered while opportunity creation theorists argue that opportunities only need differential access (Gartner, 1985; Baker \& Nelson, 2005). Further, opportunity discovery theorists assume that the entrepreneurs are bearing certain amount of risk while opportunity creation theorist assume no such trait is required but continuously hypothesizing about outcomes before exploiting opportunities to avoid uncertainty(Alvarez and Barney, 2007). Moreover, neither theorists assume that the influence of context on either uncertainty avoidance or mitigating risk when identifying and exploiting an opportunity. Opportunity identification and exploiting behaviour, according to some researchers, is the heart of 
entrepreneurship (Gartner, 1985). Empirical evidences, however, are rare which attempt to find relationship between mode of opportunity identification and wealth creating potential of small businesses although there is evidence on the influence institutional context on productive and unproductive entrepreneurship (Baumol, 1990). Taking Baumol's argument further, this study argues that wealth creating potential of entrepreneurship also varies with the institutional context.

The basis for this argument had been provided by empirical findings of some scholars. Ucbasaran et al., (2009) found that the types of entrepreneurs varies with the extent of ownership experience and categorized entrepreneurs as habitual and novices. Habitual entrepreneurs exploit opportunities sequentially or hold several businesses concurrently (Westhead et al., 2004). Considering sample used in these studies, it is evident that those entrepreneurs are from urban and in hightech industries. Kodituwakku (1997) found that rural entrepreneurs are resource constrained and failed or unsuccesful entrepreneurs are engaged in routine activities and produce only for local markets.

Combining Kodituwakku (1990)'s and Ucbasaran et al., (2009)'s findings with Baumol (1990) (context influence entrepreneurship to make them productive or unproductive), this study argue that wealth creating potential of entrepreneurship also vary with the institutional context. By raising question, 'what is the influence of context on entrepreneurship'? Since opportunity identification and exploitation behaviour is the heart of entrepreneurship, the above question is rephrased as 'what is influence of context on mode of opportunity identification'. Hence objectives of this paper are to find (i) how context develop to influence individuals adopt different types of behaviour in opportunity identification and exploitation (ii) How different behaviours influence the innovativeness of business opportunities. 


\subsection{Significance of the study}

Generally, wealth creating ability of small business is the most important factor which determines the contribution of businesses towards socio-economic development (Ucbasaran et al., 2009; Thurik and Wennekers, 1999, 2001). Although entrepreneurship is mainly concern on innovativeness (Shane, and Venkatarama, 2000), influence of context on innovativeness has been ascribed only traits of entrepreneurs (Carland et al., 1984) or characteristics or wealth creating potential of opportunities. Assessing factors influencing distribution of wealth creating opportunities across a country ignored. These factors had been ascribed to carrying capacity (customer base) or the limited market. With the current infrastructure and technological development market has not confined to physical location. Then it is needed to explain th relationship between context (institutional) and wealth creation potential of entrepreneurship. Such and explanation may help policy makers to take policy measures to use entrepreneurship as a measure for socio-economic development of the country irrespective of the difference in contexts within a country. Further, finding of such a study explore the strategies/policies need to close the gap between rural and urban entrepreneurship.

\section{Literature Review and the Conceptual Framework}

Mode of opportunity identification, according to scholars, takes two forms: opportunity discovery and opportunity creation (Alvarez and Barney, 2007). These modes of opportunity identification and exploitation take place not in a vacuum but in a context. Hence, there may be an influence of context over mode of opportunity identification and subsequent exploitation. The review given below is to find gaps in knowledge about the influence of context on mode of opportunity identification. 
Entrepreneurial opportunity, according to Shane (2003:18) is a situation in which person can create a new means-ends framework for recombining resources that the entrepreneur believes will yield a profit. This implies that opportunity is shaped by the belief of a person. Individuals beliefs and attitude, according to scholars are (Willamson, 2000) are mostly influenced by the society or the socio-cultural environment or the context. Although definition of entrepreneurship is not conclusive (Alvarez and Barney, 2007; Shane (2003) contends it is an interaction between opportunity and individual. Individual has been defined, according to literature, either by characteristics (Carland et al., 1984) or the behaviour (Gartner, 1985). Some scholars contend that behaviour of individuals is shaped by the context where they dwell (Weber. 2010). Then it is important to understand how context is made to influence the opportunity identification behaviour. This study argues that the extent of strength of formal or informal institutions determine the influence of context on mode of opportunity identification. Next section discusses how entrepreneurship is influenced by the incentive structure for exchange between producers and clients which in turn, affect the opportunity identification behaviour of individuals.

Entrepreneurship has been defined by some authors as "the process of doing something new and/or something different for the purpose of creating wealth for the individual and adding value to society" Kao, Raymond (1993). Hence entrepreneurship is a wealth creation process which involves opportunity and individual of which wealth creating potential is determined by the context or the environment. Context, on the other hand is defined Johns (2006, p. 386) context as situational opportunities and constraints that affect behaviour. These evidence suggest that individual behaviour may constrain or facilitated by the context. Since entrepreneurship is a process. As defined earlier, which governed by the incentive structure of the society. This incentive structure, according to North $(1990,1995)$ assist in reducing uncertainty and risk for individual behavior 
as well as the transaction costs connected with entrepreneurship. They "define what actors can do, what is expected from them, or they must do, and what is advantageous for them. In this way, they give stability and predictability to economic interaction." (Dallago 2000: 305). Applying North's concept to entrepreneurship, institutions are the 'formal' and 'informal' constraints and enabling forces on entrepreneurship.

Opportunity discovery is also a process where entrepreneurs make decisions, when price system failed to provide information on future goods and services (Shane 2003). This discovery process involves existence of opportunity, identification of opportunity, entrepreneurial decision making on entrepreneurial opportunity exploitation (Shane, 2003). On the other hand opportunity creation also a process by which individuals create opportunities (Alvarez and Barney, 2009). Same authors argue that opportunity discovery and opportunity creations are processes leading to new business entry or expansion of present business but under different assumptions which are not explicitly stated.

According to opportunity discovery theorists, opportunities are derived from attribute of markets or industry, and assume that opportunities are objective and waiting to be discovered (independent of individuals), and capable individuals who bear some risk exploit those opportunities. Opportunity creation is a similar process but based upon different assumptions from opportunity discovery: Opportunities are subjective, individuals are ordinary, and opportunities are subjective. According to above definitions, opportunity discovery is a process influenced by the individuals (individuals are unique in discovering opportunities) and understand the potential of opportunities. In contrast, opportunity creation theorists, assume that entrepreneurs are ordinary, opportunities are, subjective and bears uncertainty (Gartner, 1985; Saraswathie, 2001). Further opportunity creation theorists argue that opportunities cannot 
exists independent of individuals and attributes or market or the industry may not influence the decision to create opportunity. Accordingly, opportunities are created under series of hypotheses. Having defined the assumptions under opportunity creation and discovery, next it is important to understand the influence these two mode of opportunity identification on wealth creation potential which is proxy to innovativeness (Ucbasaran et al., 2009) of the opportunity discovery/creation.

Innovation is defined as the act of carrying out ideas and the innovativeness is the characteristic of the firm (Grønhaug and Kaufmann, 1988). Then the wealth creating ability, which is proxy to innovativeness (Ucbasaran et al. 2009), is a characteristic of the firm. When small business is centred on an individual entrepreneur, innovativeness becomes a characteristic of an individual. The above definitions pose a major challenge to operationalize the research question of the study "how the context influences the mode of opportunity identification on innovativeness of small businesses'.

Above reviewed literature lead this study to develop propositions on which conceptual framework is framed.

Proposition i. Context where formal Institutional are strong may conducive for opportunity discovery while contexts where informal institutions are strong may conducive for opportunity creation process.

Proposition ii. Opportunity discovery process create more innovative business opportunities than opportunity creation process.

Proposition iii. Either opportunity discovery or opportunity creation process is influenced by the institutional context.

Returning to the objectives of this study, proposition $\mathrm{i}$ address the first objective while the ii and iii addresses the second objective of this study. 
Accordingly following conceptual framework is developed.

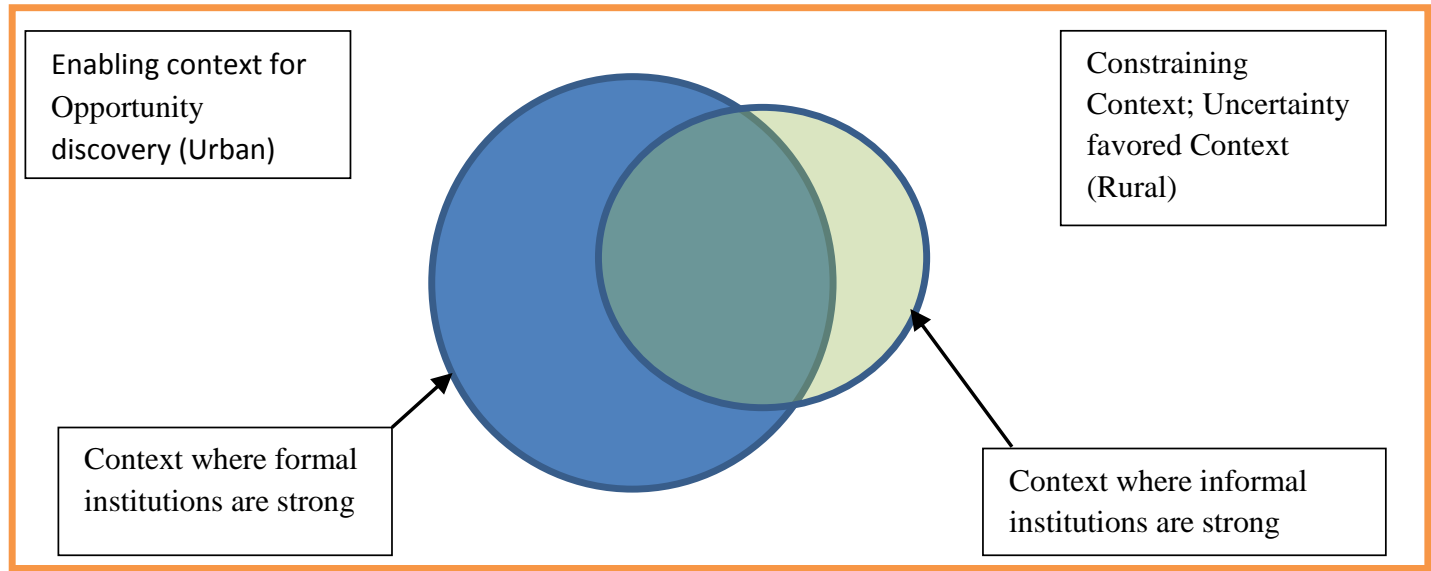

\section{Figure.1: Conceptual Framework}

\section{Methods}

Some researchers advocate adopt inductive approach particularly case study method to building theories in areas where theories are deficient (e.g., Eisenhart, 1989; Yin, 2003). Yin further states that 'how' and 'why' questions are most pertinent to case study strategy when the researcher has no control over contemporary event under consideration; more preciously, at times when relevant behaviour cannot be manipulated. Case study method has advantages over historical method which is a contender for case study method. Because case study method accommodate direct observations of the event being studied and the interview of the persons involved in the events.

The major advantage of case study method in investigating contemporary phenomenon is that it takes context in to consideration. Low and McMillan (1988), emphasizing importance of context, states that entrepreneurship could best understood within the context. Therefore research design plays a major role in isolating phenomenon under consideration from the context. The unit of analysis of this study is the condition at which opportunity identification takes place. Then the next unit of analysis embedded in the context is entrepreneurial 
opportunity identification process. Therefore this study has embedded units of analysis in consistent with the case study research method (Yin, 2003:45). The higher level unit of analysis is context which will be measured on characteristics of geographic and demographic characteristics and lower level analysis is individual small business owner's behaviour on opportunity identification processes.

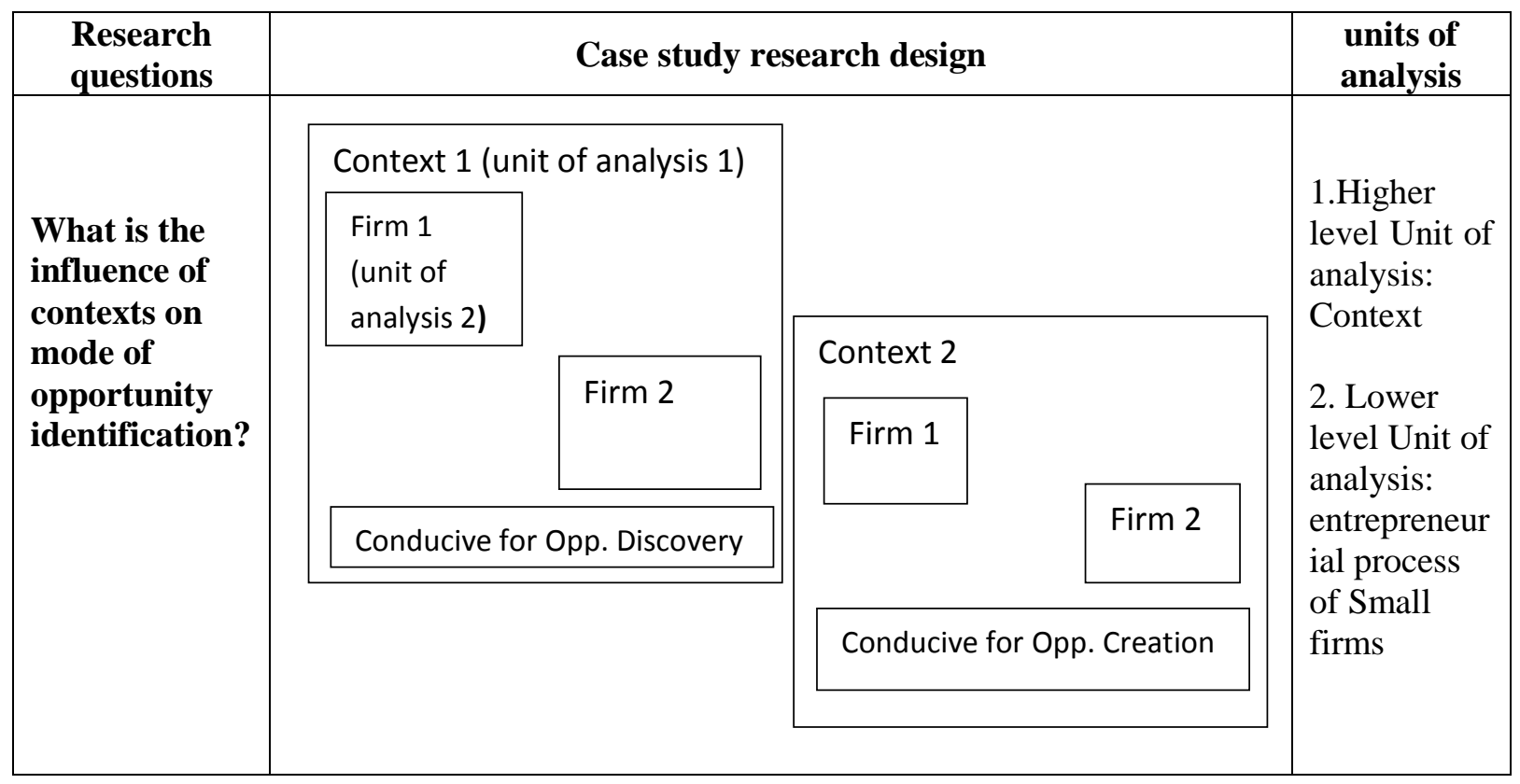

Figure 2: Research design and the units of analysis of the study

The next task is selecting a location which gives rise to uncertainty or risk. Generally, small businesses emerge under risk or uncertainty within every context. However, in some contexts, the number of opportunities identified under uncertainty is greater than those opportunities under risk. According to Shane (2003: 59), prior business experience is the most influential factor which influences individuals to discover wealth creating opportunities. Then it is reasonable to select locations which give rise to more business experience and least business experience. 
Generally, individuals in townships are more exposed to businesses than those in the rural settings. When the rural setting is evolve only to survive, then individuals in those societies are less likely to expose to exchange which involve profit (business activities). This situation becomes more prominent when individuals in these societies attempt to share resources rather adding values. As a result entrepreneurs in these setting have no alternative other than creating opportunities since they are unaware of the probability of outcomes as rural entrepreneurs. To illustrate this difference prominently, this study select Kurunegala Township which won the award best township in the Island and Degoda-thurawa village which located about 61 kilometers from Kuruenagala and surrounded by two mountains and a jungle.

This study selected all the businesses in the most wealth creating ward in the township (Ward No.4) and all the business activities of the village. From 178 business activities in the rural setting all non-commercial agricultural activities were eliminated and selected only business activities which create values and ranked them. Three top ranked businesses were selected and conducted in-depth studies. Similarly, eliminated all retail businesses from 111 businesses in the Ward No.4 of the township and selected value added business only. Then selected businesses ranked according to wealth creating potential according to information received from competitors and revenue collectors. To support the argument of this study, selected three demonstrating cases from each context which are given in the section 4.

\section{Analysis of context}

To minimize natural variables, selected a township located in the intermediate zone. Kurunegala District is the one which meets above requirement to minimize variation in climate. Its geographical location is ideal to maximize contextual variables. When accessibility is concerned, main roads to Northern 
and Eastern parts of Sri Lanka runs through Kurunegala Township. The distance to Colombo, capital city, is $100 \mathrm{~km}$ while $45 \mathrm{~km}$ to the second largest city Kandy. Racial harmony exists in the township where all three religious groups are running their businesses in the town. The town ship was divided several sections according to types of trade. Ward No.4 in which this study was conducted is the highest wealth creating section in the town since it deals with motor vehicles and motor spare parts. All three major plantation crops are grown in the district but coconut is the main livelihood of people. Generally coconut is considered as a crop which absorb least labour and gives ample time for other activities.

In contrast, selected location for rural context is located about 60 kilometers towards Mahawa along Kurunegala-Mahawa road via Galtan-wewa. This village is surrounded by two mountains (Degoda-thurawa and Ihalagma) from the East and North. South is bordered by Mal-Asna village and the west is bordered to Wadupolayaya-gama. The villagers descended from mountains before hundred years ago (informant evidence) when they confronted with Malaria. Only two surnames are used in this village and most probably adopted when they settled in the plain. Ever since they lived together by cultivating paddy lands belonged to Niyanda-wila temple. There are two small tanks in the village to provide water to paddy fields. Homesteads were small and limited to quarter of an acre to half an acre. Currently there are 178 families and have over ten societies in the village but Maranadhara Samithiya (society to support at funerals) is the most active one. This village is self-evolved to sustain their livelihood over centuries and no exposure to innovative businesses for last three decades. Moreover, it is important to understand the self-evolved village from a village setup under the intervention of government (e.g., Mahaweli Settlement; Please see Kodituwakku and Rosa, 2002 for more details about a village setup under government intervention). 


\subsection{Overview of the cases selected}

Case U1 was about a youth who wanted to do business of his own but exactly does not know what business $d$ to begin with. His father was a teacher who taught engineering drawing in a leading college in the town. His mother was a house wife and had a brother. From the childhood he used to repair his father's motor cycle and became conversant with motor cycle repairs. During that time Kurunegala was famous for importing reconditioned motor cycles and started motorcycle repairs as a business in 1986. He hired an experience mechanic and obtained support from his brother. However the business was not successful and decided to do contracts in Mahaweli area and engaged in contracts from 1988 to 1990. When the contracts are diminishing, returned to his former workshop and started making florescent tubes with his brother (Case 2).

During that period televisions were introduced to Sri Lanka and people are interested in watching TV and lighting their houses. With help of National Engineering Research Institute (NERI), they started making florescent tubes for from 1991 to 1994. In the meantime more produces entered into the market and decided to close the business and started making rice-planters on with the advice from Mahaillluppalama Farm Machinery Centre (FMRC). During this period they were selected to tour several countries on a partial subsidy provided by FMRC. In Australia he show pre-fabricated iron frame manufacturing industry and decided to start that business in Sri Lanka. While in the pre-fabricated iron frames production, in 1995, he started making water bowsers to meet the demand for water in war-torn area in the North and East. In 1997 he started supplying water to local area using unsold water-browsers and the water from own well (The well is unique to that area with unlimited water harvest). Currently he is doing pre-fabricated frames, water browsers manufacturing, and water suppliers to local area. The chronological order of opportunities discovered in given in the Appendix 1. 
Case U2 is about a youth who also wanted to do business after schooling. He couldn't complete his GCE (OL). After schooling, he started business with his brother until 1994 on the business given in the case U1. After ending the association with his brother, he started his own business, first started with making nuts and bolts for Ceylon Electricity Board (CEB) on contract basis. To make some specific items he developed some machinery specifically for those items. When contracts with CEB were over, he started making desks and chairs for Department of Education in 1999. These opportunities were created through a special education project launched by the government and continued the business until 2001. With the difficulties he faced on obtaining government contracts (corruptions and quality standards) he decided to start a stable business with reasonable profit (during this time he was married and had two children). The business he selected was vehicle servicing which needs fixed machinery (hoister and high water pressuriser) and labour. He understood that profit margin could be increased by making cleaning liquid by him. Currently he is continuing his business. The chorological order of the career in business is given in the appendix 1.

Case U3 is about a person who had no formal education but had business experience from the childhood. The owner had education only up to 8th standard. But he had been working in his father's business (charcoal) while schooling. When he was 20 years old he thought of doing his own business and searched opportunities. He started his business by winning a quotation for old tires for then State Paper Corporation at Valchchenei in 1970s. While he was supplying old tires, he got familiar with the Northern Province. He soon understood the resources in North and surpluses in North-Western province and started bringing salt from Elephant-pass in the returning empty. While taking old tires he found business of supplying charcoal to jewellery manufacturers in the North. When the contract was over in 1984, he continued supplying charcoal (carbon made out 
of burning coconut shells) to the North and bringing back salt to Kurunegala. When the ethnic war broke-out in the early 1980s he embarked into importing motor cycles in which period reconditioned motorcycle business was flourishing in Kurunegala. When reconditioned motorcycles are ruining short in Japan and the competition was severe, he started importing bikes from Singapore which market has not been fully explored. In the meantime he noticed that silencers could be manufactured locally and it is the most vulnerable components in Japanese bikes since the silencer production at time was lucrative he imported mechanics from South India. Seeing an internet advertisement for old Bedford engine parts to Canada, he exported some Bedford Parts to Canada in 1999. He fell ill (paralyzed) in 2000 but continued to work in the silencer production.

Major themes emerging from the Cases: Exposure to business has influenced all cases to discover subsequent business opportunities irrespective of knowledge in the relevant industry. All entrepreneurs are innovative and exploit opportunities one after another [(serial entrepreneurs (e.g., Ucbasaran et al. 2009)] and searched for opportunities for better wealth creating capacities. With accumulated business experience, entrepreneurs were able to take calculable risk. The context has stimulated them to seek more opportunities with greater wealth creating capacities.

\subsection{Cases in rural context:}

Case R1 is about a farmer who became an entrepreneur over time. He had no formal schooling and from the early childhood he started farming. He started his business career in 1960s by collecting coconuts from village homesteads. First he sold fresh nuts and later made copra from remaining nuts. Since money is limited for cash settlements he converted part of his house to boutique to exchange goods for coconuts in 1978. This exchanged process expanded to include paddy and non-perishable crops (grains) by employing his wife as the 
care-taker of the boutique. When he became comparatively wealthy man in the village, he was elected to presidency of the 'Awamangaladara society (Society which help for funerals)' in which he had to safe guard money. During the period of insurrection in 1989, Rupees 12,000.00) was stolen and went bankrupt ever since. He closed down his boutiques and started farming again in 1990. In the meantime the village (Degoda-thurawa was selected for external funding (FAO) for pipe-borne water project (drinking water was the most acute problem in the village) and started working on it for wages in 1997. After marrying his daughter to a youth worked for project, he handed over all business activities to son-in-law. Currently they bought a two-wheel tractor and earned an extra income by hiring the tractor. Table for R1 is given in the appendix 1 .

Case R2 is about a person who embarks into business to exploit an opportunity with infrastructure development (electricity). The person was working as a clerk for 15 years and started an electrified paddy mill at the age of 51years in 2005. Before the mill he was used his extra time for farming vegetable but sold the produce at Dhambulla market about 35 kilometres away from the village. He decided to design paddy mill to eliminated problems inherent in diesel driven paddy mills in the surrounding villages. The milled paddy in traditional mills contained more broken - rice and refused wet rice into mills to turn them into flour (rice flour is important input for making traditional sweets). Grinded chillies and other essential commodities used in traditional cooking in fuel diven mills were not in good quality and took greater time for milling. He innovatively designed his mill to eliminated most of the problems inherent in traditional mills and employed his wife as its manager-operator. To build his mill borrowed money from three friends to purchase equipment. The huller was bought on a loan from a merchant in the Galtan-Wewa junction. Table for Case R2 is given in the appendix 1. 
Case R3 is a case against the argument of this study. That is self-evolving societies may give rise to non-innovative opportunities. R3 is a case which attempts to exploit niche market outside to the context, organizing traditional industry in an innovative way, and exploiting new infrastructure and existing advantages in the village setting to the maximum. The mill is owned by a youth about 30 years of age. The mill was installed close to the Ihalagama Mountain and in the shrubs. The owner was a son of businessmen running the largest boutique in the area Niyandawila, adjoining Degoda-thurawa village.

When R3 was schooling he used to help his father and took care of retail business. He schooled in the Niyanda-wila junior school and went for Advance Level studies to Kurunegala town. Soon after schooling he organized mill to produce raw-rice at large scale in 2005. He employed 6 persons for the industry and installed electricity driven machines. Although his main produce was rawrice, market for raw-rice was not abandon in Kurunegala District and took some risk to exploit a niche market. To exploit lower prices of paddy in the village, he purchase local paddy from the village and went for distances when the prices are falling in the harvesting seasons in major paddy producing areas (i.e., Anuradhapura and Polonnaruwa).

Major themes emerging from Cases in rural setting: Cases in rural setting, except R3, are confined to one opportunity and gives priority to main occupation. It could either be farming main crop, paddy, or occupation. All business activities are subsidiaries of main occupation which had been evolved over centuries. Business emerged in the village are related to main crops either paddy or coconuts which may help avoid uncertainty. R3 is the case which challenge the argument that businesses emerging in societies which evolved only to sustain lives. The rationale of such behaviour may be the prior exposure to businesses and wealth creating abilities of rural entrepreneurs. This case shows that 
uncertainty avoiding behaviour could be changed into risk taking behaviour by accumulating business experience.

\section{Results and Discussions}

The objectives of this study, as given in the section 1 are (i) How context develop to influence individuals adopt different types of behaviour in opportunity identification and exploitation (ii) How different behaviours influence the innovativeness of business opportunities. As shown from Table 1, selected cases, $\mathrm{U} 1, \mathrm{U} 2$ and $\mathrm{U} 3$ discovered and exploit opportunities serially and U1 ended up as a portfolio entrepreneur operating several businesses simultaneously. With the business experience U1 and U2 expanded the area of opportunities beyond the limits of Kurunegala District. However, Cases U1 and U2 ended up with less innovative opportunity after discovering series of opportunities. Most influence factor for all three cases is the context which give rise to discovery of opportunities with taking calculable risk.

Table1: Themes emerging from cases and their relationships to mode of opportunity identification

\begin{tabular}{|c|c|c|}
\hline Cases & Themes emerging from cases & $\begin{array}{c}\text { Mode of } \\
\text { opportunity } \\
\text { identification }\end{array}$ \\
\hline \multicolumn{3}{|l|}{$\begin{array}{l}\text { Urban } \\
\text { setting }\end{array}$} \\
\hline $\mathrm{U} 1$ & $\begin{array}{l}\text { i. Opportunities are discovered continuously and } \\
\text { ended up with portfolio of opportunities. ii. U1 } \\
\text { is risk taker and not confined to the context } \\
\text { where he is embedded. iii. Business network } \\
\text { had been a stimulator for risk-taking behaviour. }\end{array}$ & $\begin{array}{l}\text { Opportunities are } \\
\text { discovered under } \\
\text { risk }\end{array}$ \\
\hline $\mathrm{U} 2$ & $\begin{array}{l}\text { i. Opportunities are discovered continuously and } \\
\text { stops at a less-innovative opportunity. ii. Urban } \\
\text { setting had been had a stimulator initially. iii. } \\
\text { Family networks had been stimulator for } \\
\text { opportunity seeking behaviour. }\end{array}$ & $\begin{array}{lr}\text { Opportunities } & \text { are } \\
\text { discovered under } \\
\text { risk }\end{array}$ \\
\hline
\end{tabular}




\begin{tabular}{|c|c|c|}
\hline Cases & Themes emerging from cases & $\begin{array}{c}\text { Mode of } \\
\text { opportunity } \\
\text { identification }\end{array}$ \\
\hline $\mathrm{U3}$ & $\begin{array}{l}\text { i. Opportunities are discovered continuously. ii. } \\
\text { Urban business network had been a stimulator. } \\
\text { iii. U3 had not been confined to the context } \\
\text { where he is embedded. }\end{array}$ & $\begin{array}{l}\text { Opportunities are } \\
\text { discovered under } \\
\text { risk }\end{array}$ \\
\hline \multicolumn{3}{|l|}{$\begin{array}{l}\text { Rural } \\
\text { setting }\end{array}$} \\
\hline R1 & $\begin{array}{l}\text { i. Remained in the opportunity created at the } \\
\text { beginning for his business life. } \\
\text { ii. Confined only to village resources and } \\
\text { social networks }\end{array}$ & $\begin{array}{l}\text { Opportunities were } \\
\text { created }\end{array}$ \\
\hline $\mathrm{R} 2$ & $\begin{array}{l}\text { i. Remained in the opportunity created at the } \\
\text { beginning and seek expansions internally. } \\
\text { ii. Confined only to village resources and } \\
\text { social networks. }\end{array}$ & $\begin{array}{l}\text { Opportunities were } \\
\text { created }\end{array}$ \\
\hline R3 & $\begin{array}{l}\text { i. Remained in the opportunity discovered at } \\
\text { the beginning. } \\
\text { ii. Seek expansions internally. } \\
\text { iii. Confined to village resources and social } \\
\text { networks } \\
\text { iv. Discovered external niche markets. }\end{array}$ & $\begin{array}{l}\text { Opportunities were } \\
\text { created but market } \\
\text { was discovered. }\end{array}$ \\
\hline
\end{tabular}

Table 2 given below shows that how context influence the mode of opportunity identification. The factors which give rises to opportunity discovery were nature of networks. Business networks favoured opportunity discovery while social networks stimulated creation of opportunities since they have no prior business experience. 
Table 2: Analysis of context in terms constraining/stimulating mode of opportunity identification

\begin{tabular}{|l|l|l||l|l|l|l|}
\hline & $\begin{array}{c}\text { Availability } \\
\text { of } \\
\text { opportunities }\end{array}$ & $\begin{array}{c}\text { Nature } \\
\text { of } \\
\text { networks }\end{array}$ & $\begin{array}{c}\text { Stock of } \\
\text { resources }\end{array}$ & \multicolumn{3}{|c|}{$\begin{array}{c}\text { Influence on mode of opportunity } \\
\text { identification }\end{array}$} \\
\hline & & & & Uncertainty & $\begin{array}{l}\text { Mitigating } \\
\text { risk }\end{array}$ & $\begin{array}{l}\text { Opportunity } \\
\text { discovery/creation }\end{array}$ \\
\hline $\begin{array}{l}\text { Rural } \\
\text { context }\end{array}$ & Low & Social & Low & Yes & - & + for creation \\
\hline $\begin{array}{l}\text { Urban } \\
\text { context }\end{array}$ & High & Business & High & - & Yes & + for discovery \\
\hline
\end{tabular}

The relationship between modes of opportunity identification and innovativeness is given in the Table 3. While two cases in rural setting support the argument that self-evolved homogeneous societies give rise to creation of opportunities under uncertainty, R3 give deviate from the argument about the innovativeness. R3 discovered niche market and organized his paddy mill innovatively. The deviation also falls in line with the argument that business experience had influence R3 to create opportunities with more wealth creating capacity.

Table 3: Mode of opportunity identification and innovativeness of opportunities

\begin{tabular}{|c|c|c|c|c|c|c|c|c|}
\hline \multirow[b]{3}{*}{$\begin{array}{l}\text { Urban } \\
\text { setting }\end{array}$} & \multicolumn{4}{|c|}{ Mode of Opportunity Identification } & \multicolumn{4}{|c|}{$\begin{array}{c}\text { Innovativeness of } \\
\text { Opportunity exploited } \\
\text { /business }\end{array}$} \\
\hline & \multicolumn{2}{|c|}{ Discovery } & \multicolumn{2}{|c|}{ Creation } & \multicolumn{2}{|c|}{ Discovery } & \multicolumn{2}{|c|}{ Creation } \\
\hline & $\begin{array}{l}\text { Avoiding } \\
\text { uncertainty }\end{array}$ & $\begin{array}{l}\text { Mitigating } \\
\text { risk }\end{array}$ & $\begin{array}{c}\text { Avoiding } \\
\text { uncertainty }\end{array}$ & $\begin{array}{l}\text { Mitigating } \\
\text { risk }\end{array}$ & High & Low & High & Low \\
\hline Case U1 & & Yes & & & Yes & & & \\
\hline Case U2 & & Yes & & & Yes & & & \\
\hline Case U3 & & Yes & & & & Yes & & \\
\hline $\begin{array}{c}\text { Rural } \\
\text { setting }\end{array}$ & & & & & & & & \\
\hline Case R1 & & & Yes & & & & & Yes \\
\hline Case R2 & & & Yes & & & & & \\
\hline Case R3 & & & & Yes & & & & \\
\hline
\end{tabular}




\section{Discussion}

Previous entrepreneurship literature suggest that context influence entrepreneurship to emerge as either into productive or unproductive entities. This study build a similar argument using theory of institutions which claims that incentive structure of a context is determined by the institutions. Informal institutions evolved to survive favours opportunity creation process and the opportunities are created under these condition may with low wealth creation potential as shown in the Table 3 . Table 2 shows this argument more prominently on the basis of opportunity availability, nature of networks, and stock of resources embedded in networks. Table 1 shows the mode of opportunity identification according to the data collected from in-depth interviews. Evaluating current businesses owned by entrepreneurs, this study found that enterprises created under uncertainty are relatively less innovative than those of enterprises emerge under opportunity discovery.

As the reason for this contrasting opportunity identification behavior, this study found that informal institutional context evolved over sometime does not favour exploitative behaviour. Hence entrepreneurs in these setting take long time to establish business with low wealth creating potential. However, entrepreneurs in the rural who have exposed prior business experience have discovered more innovative opportunities. In contrast, urban entrepreneurs discover more innovative sequentially by taking risk. Since formal institutions are structures with some predictability, urban entrepreneurs take calculate risk to identify and exploit more opportunities.

\section{Conclusion}

The cases presented here support the argument of this study that mode of opportunity identification has an influence over the wealth creating potential of the opportunity created or discovered. While opportunity creation mode brings 
about less wealth creating opportunities, opportunity discovery mode, very often, gives rise to more wealth creating opportunities. According to the findings of this study, the reason for this contrasting behavior is relative strength of formal or informal institutions in respective contexts.

Findings of this study pose serious concern about the current policies on social and economic development. The findings indicate that inertia had created in rural setting due to social networks, norms and tradition evolved over some time. By exposing rural entrepreneurs more business experience, according to findings of this study.

\section{References}

Baker, T., and Nelson, R. 2005. Creating something from nothing: Resource construction through entrepreneurial bricolage, Administrative Science Quarterly, 50(3): 329-366.

Baumol, W. (1990). Entrepreneurship: Productive, Unproductive, and Destructive, Journal of Political Economy, 98(5), 893-921.

Burt, R. (1992), Structural Hole: The Social Structure of Competition, Boston, US, Harvard University Press.

Central Bank Annual Reports, Various Issues, Central Bank of Sri Lanka, Colombo.

Central Bank of Sri Lanka (2005). 'Consumer Finances and Socio-Economic Survey Reports 2003/2004', Sri Lanka, Colombo.

Dallago, B. (2000). "The Organisational and Productive Impact of the Economic System. The Case of SMEs." Small Business Economics 15: 303-31 9.

Dreyer, B. and Gronhaug, K. (2004). 'Uncertainty, Flexibility, and Sustained Competitive Advantage', Journal of Business Research, 57; 484-494.

Eckhardt, J. and Shane, S. (2003). The Importance of Opportunities to Entrepreneurship. Journal of Management, 29(3). 
Eisenhardt, K. (1989). Building Theory from Case Study Research, Academy of Management Review, 14(4): 532-550.

Gartner, W. (1985). A Conceptual Framework for Describing the Phenomenon of New Venture Creation, Academy of Management Review, 10, 696 -706.

Gartner, W. B., Reynolds, P. D., and Carter, N. M., and Greene, P. G. (2004). The Prevalence of Nascent Entrepreneurs in the United States: Evidence from the panel study of entrepreneurial dynamics Small Business Economics 23 (4), 263-284

Gartner. W.B. (1988). "Who is an Entrepreneur" is the Wrong Question, American Small Business Journal (spring).

Grønhaug, K., G. Kaufman. (1988). Innovation: A Cross-Disciplinary Perspective, Norwegian Univ. Press, 530 p.

Johns, G. (2006). The Essential Impact of Context on Organizational Behaviour. Academy of Management Review, 31(2), 386-408.

Kirzner, I. (1985), Entrepreneurial Discovery and the Competitive Market Process: an Austrian Approach, The Journal of Economic Literature, 35, 60-85.

Kizner, I., (1979). Perception, Opportunity, and Profit, University of Chicago Press, Chicago.

Knight F, (1921), Risk, Uncertainty, and Profit, New York, US: Augustus Kelly.

Kodituwakku, K.A.S.S. (1997). Entrepreneurial Process in an apparently uniform context: A study of rural farmers in Sri Lanka, Unpublished PhD. Thesis, University of Sterling.

Low, M.B. and MacMillan, I.C. (1988). Entrepreneurship: Past research and future challenges. Journal of Management, 14(2), 139-161.

Miles, M. \& and Huberman,A. M. (1984). Qualitative Data Analysis, Beverly Hills, CA, Sage Publications. 
Miller, D. and Shamsie, J. (1996). The Resource-based view of the Firm in Two Environments: The Hollywood Film Studios from 1936 - 1965, Academy Management Journal, 39(5), 519-36.

North, D.C. (1990). Institutions, Institutional Changes and Economic Performance, New York: Cambridge University Press.

Raymond, K. W. Y. (1993) Defining entrepreneurship; past, present and? Creativity and Innovation Management, 2(1). Basil Blackwell Ltd

Raymond, K. W. Y. (1993) Defining entrepreneurship; past, present and? Creativity and Innovation Management, 2(1). Basil Blackwell Ltd'

Sarasvathy, S.D. (2001). "Causation and effectuation: Toward a theoretical shift from economic inevitability to entrepreneurial contingency." Academy of Management Review 26 (2): 243-263.

Shane, S. and Venkataraman S. (2000). The promise of entrepreneurship as a field research, Acad. Mange. Rev. 25 (1), 217 -226.

Shane, S. (2003). A General Theory of Entrepreneurship: The Individualopportunity Nexus, Cheltenham: Edward Elgar

Shane, S. (2000). Prior Knowledge and the Discovery of Entrepreneurial Opportunities, Organization Science, 11(4):448-469.

Thurik, A. R. and Wennekers, A.R. M. (2001). "Entrepreneurship, Economic Growth and the Significance of the GEM project" In Reynolds, P.D., Camp, S. M

Ucbasaran, D, P. Westhead and M. Wright (2006). Habitual Entrepreneurs', in M. Carson, B.Yeung. and N. Wadeson (eds). The Oxford Handbook of Entrepreneurship, 461:482.

Ucbasran,D. (2004a). Opportunity Identification Behaviour by Different Types of Entrepreneurs. In Butler, J. 9 (Eds), Opportunity Identification and Entrepreneurial Behavior, Research in Entrepreneurship and Management Series, IAP. 
Welter, F. (2010). Contextualizing entrepreneurship-Conceptual challenges and ways forward, Entrepreneurship Theory and Practice, 165-184.

Welter, F.(2012) In: Enterprising Families in a Hostile Environment for Entrepreneurship, Eds. Welter, F., Smallbone, D., Slonimski, A., Linchevskaya, O., Pobol, A. and M. Sloniska, Jönköping International Business School.

Wennekers, A.R.M. and Thurik, A.R. (1999). Linking Entrepreneurship and Economic Growth, Small Business Economics, 13 (27-55).

Westhead, P., D. Ucbasaran, and M. Wright (2003a). Difference between Private Firms Owned by Novices, Serial and Portfolio Entrepreneurs, Journal of Business Venturing, 19, 173-188.

Westhead, P., Ucbasaran, D., Wright, M. (2004). Policy towards Novices, Serial and Portfolio Entrepreneurs, Environment Planning and Government Policy 22, 779-798.

Willamson, O. E. (2000). "The New Institutional Economics: Taking Stock, Looking Ahead," Journal of Economic Literature 38(3), 595-613.

Yin, R. K. (2003). Application of Case Study Research: Design and Methods, Sage Publishers, London.

Yin, R. K. (2003). Case Study Research: Design and Methods, Sage Publishers, London.

Zahra, S., \& Dess, G.G. 2001. Entrepreneurship as a Field of Research: Encouraging Dialogue and Debate, The Academy of management Review, 26(1): $8-10$. 